\title{
Aniversário do D.A.S.P.
}

\section{$\mathrm{E}$}

SPECIAL significação teve o vigésimo segundo aniversário da criação do D. A. S.P. a 30 de julho último, comemorado em Brasilia, com a presença de S. Excia., o Presidente da República.

Também nessa data, vê o D.A.S.P. as suas funções ditatadas por novas atribuições, decorrentes da Lei $n^{\circ} 3.780$, de 12 de jultho do corrente, criando no D.A.S.P., a Divisão de Classificação de Cargos, pelo art. 39, e a Comissão de Classificação de Cargos, junto a êsse Departamento, segundo o artigo 36 do referido diploma legal. Além de transformar a Divisão de Pessoal do D.A.S.P. em Divisão do Regime Juridico do Pessoal, pelo artigo 42, e incorporar os Cursos de Administração à Escola de Administração, no art. 59.

Ficou, assim, o D. A.S. P. estruturado em cinco Divisões, dentre as quais três tratam da administração do pessoal civil da União e duas de orçamento, organização e de edifícios públicos.

Ressalta, nessa comemoração de aniversário, a coincidência dos propósitos da Lei $n^{\circ}$ 284, de 1936, que criou o Conselho Federal do Serviço Público Civil e que deu origem ao D.A.S.P. (primeira tentativa racional de estruturação do pessoal civil da União) e a presente Lei de Classificação de Cargos, que, vinte e quatro anos depois de incansáveis esforços, alcançou o objetivo visado pelos pioneiros da implantação de uma administração técnica e racional no Brasil.

Apesar de cronològicamente curta, a história do D.A.S.P. é intensamente vivida. Durante os vinte e dois anos de sua existência, participou de tôdas as atividades de vulto da administração federal, constituindo orientação e exemplo da Administração estadual e municipal e mesmo privada.

Na luta da racionalização administrativa no Brasil, tem sido êste Departamento o pequeno David, lutando contra o Golias da corrução e do nepotismo, existentes no serviço público civil da União. 
Quanto ao resultado dessa luta, basta que citemos mais de uma centena de milhar de candidatos selecionados em provas e concursos para exercer funções e cargos do serviço público federal; mais de uma dezena e meia de propostas orçamentárias da União; centenas de regulamentos, regimentos e outros atos administrativos, como a unificação racionalizada da jurisprudência de pessoal, de material, de obras públicas e orçamentária. Sem mencionar a sua participação no Plano Salte, na elaboração do Estatuto dos Funcionários Públicos Civis da União, de 1939 (o primeiro existente), como também a planificação e organização de vários órgãos administrativos e a criação dos sistemas de pessoal, material, organização e orçamento, implantando os Serviços de Administração, em todos os ministérios civis. Lembremos, ainda, os subsidios técnicos à elaboração de projetos de leis especializados de Administração geral, destacando-se entre todos o Plano de Classificação de Cargos, cujos vários projetos foram obra do D.A.S.P., como o que ora se transformou em lei e por cuja boa execução será o D. A. S. P. responsável.

Não deve ser esquecida, de outro lado, a ajuda técnica que o D.A.S.P. deu aos Estados da União e aos Municipios, na criação dos seus Departamentos do Serviço Público, implantando o sistema do mérito na administração local e racionalizando a técnica orçamentária, a do enquadramento do pessoal civil e sua remuneração, bem como a moralização e a padronização nas compras do material administrativo.

O D.A.S.P. foi criado pela inspiração doutrinária de Willoughby. Walker, White e de outros autores da técnica administrativa dos Estados Unidos e da Inglaterra, fundamentando-se na experiência, que tão bons resultados deu naqueles paises; porém. superou, no Brasil, tudo o que havia de antecedente na América do Norte e na Europa.

Hoje é o D.A.S.P., sem nenhuma dúvida, o mais completo órgão de administração geral existente no mundo, tendo realizado com êxito a mais vasta revolução racionalizadora, levada a efeito por um órgão de sua natureza. Como prova dessa afirmativa há testemunho de declrações esparsas de autoridades administrativas dos Estados Unidos, da França, de Istael e de outros paises mais evoluidos. 